НАУКОВИЙ ВІСНИК

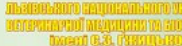

Vecteriessenger of Lviv

Veterinary Medicine and Biotechnologies

tow

है कै है

1 if 1 if

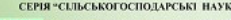

Том 22 № 92

2020

Науковий вісник Яьвівського національного університету ветеринарної медицини та біотехнологій імені С.3. Гжицького. Серія: Сільськогосподарські науки

Scientific Messenger of Lviv National University of Veterinary Medicine and Biotechnologies. Series: Agricultural sciences

UDC 636.087.8: 611.3

\title{
Morphological indicaters of the gastrointestinal tract of young pigs during feeding of the PVMS "Efiprot"
}

\author{
V. S. Vuhliar \\ Vinnytsia National Agrarian University, Vinnytsia, Ukraine
}

Article info

Received 07.02.2020

Received in revised form 09.03 .2020

Accepted 10.03.2020

Vinnytsia National Agrarian University, Sonyachna Str., 5 Vinnytsia, 21008, Ukraine. Tel.: +38-098-933-41-00

E-mail:Vasja.vugljar@rambler.ru
Vuhliar, V. S. (2020). Morphological indicaters of the gastrointestinal tract of young pigs during feeding of the PVMS "Efiprot". Scientific Messenger of Lviv National University of Veterinary Medicine and Biotechnologies. Series: Agricultural sciences, 22(92), 71-75. doi: 10.32718/nvlveta9212

The problem of increasing of livestock and poultry has led scientists to look for measures to improve productivity and reduce costs. One way to solve this problem is to use balancing supplements in the feeding. The study of feeding by protein-vitamin-mineral feed supplement "Efiprot" was carried out on three groups of young white pigs, 12 heads in each group. The experiment consisted of leveling of 15 and a basic period of 127 days. During the rearing period, the animals consumed the feed according to the growth phases, increasing the amount from $1 \mathrm{~kg} / \mathrm{head}(8-15 \mathrm{~kg}$ of live weight), up to $1.5 \mathrm{~kg} / \mathrm{head}$ per day (15-35 kg of live weight) and from $2 \mathrm{~kg} / \mathrm{head}$ (35-65 $\mathrm{kg}$ of live weight) and up to $2.5 \mathrm{~kg} / \mathrm{head}$. per day (65-110 kg of live weight). While using in feeding of young pigs of PVMS "Efiprot", a positive productive effect was obtained. Thus, when introduced to the diet of the tested yong pig the PVMS, the average daily growth of animals has increased by 33-58 g. Accordingly, has increased the final live weight of the animals by $4.05-7.18 \mathrm{~kg}$ against the control level. Due to the result of the studies, carrying out the control slaughter, it was found that feeding of the protein-vitamin-mineral supplement "Efiprot" for young pigs on rearing does not have a probable effect on the weight of the stomach, but causes changes in the thickness of the wall of the cardiac zone by $0.24 \mathrm{~mm}(2.75 \%)$, and reducing the wall thickness relative to the control by $1.04 \mathrm{~mm}(11.91 \%)$. In the fundus zone of the stomach, there is a tendency to thicken the walls due to the mucous and seremuscular membranes by $0.36 \mathrm{~mm}(6.75 \%)$ and $0.35 \mathrm{~mm}(6.56 \%)$. In the study of the pyloric zone, the thickness of the walls was decreased by $0.46 \mathrm{~mm}(3.13 \%)$ and $0.73 \mathrm{~mm}(4.97 \%)$ compared to the control group.The reaction of the intestine to feeding of "Efiprot" to young pigs is caused by an increase in weight and length of $0.06-0.2 \mathrm{~kg}$ and $0.5 \mathrm{~m}-0.83 \mathrm{~m}$. Also it is shown a slight decrease in the thickness of the hollow shell by $0.5 \mathrm{~mm}(18.3 \%)$ in the second group of animals $0.21 \mathrm{~mm}(7.69 \%)$. A significant difference was found in the structure of the colon of experimental animals, where there was an increase in wall thickness in the first group by $0.13 \mathrm{~mm}(5.75 \%)$ and a decrease in the second group by $0.16 \mathrm{~mm}$ (7.07\%).

Key words: essential oils, young pigs, growing, stomach, stomach lining, intestines.

\section{Морфологічні показники шлунково-кишкового тракту молодняку свиней при згодовуванні БВМД “Ефіпрот”}

\author{
В. С. Вугляр
}

Вінницький національний аграрний університет, м. Вінниця, Україна

Потреба збільшення поголів'я сільськогосподарських тварин та птиці спонукає науковиів до пошуку заходів, спрямованих на підвищення продуктивності та зменшенням витрат. Одним зі шляхів вирішення иієї проблеми є використання балансуючих добавок в годівлі. Дослідження згодовування БВМД “Ефірот" проведено на трьох групах молодняку свиней великої білої породи, по 12 голів у кожній. Дослід складався зі зрівняльного - 15 та основного періодів - 127 діб. У період вирощування тварини споживали корм згідно з фазами росту, кількість його збільщувалась від 1 кг/гол. (8-15 кг живої маси) до 1,5 кг/гол. за добу (15-35 кг живоі маси) та від 2 кг/гол. (35-65 кг живої маси) і до 2,5 кг/гол. за добу (65-110 кг живої маси). При застосуванні в годівлі молодняку 
свиней БВМД “Ефіпрот” було одержано позитивний продуктивний ефект. Так, при введенні в раціон досліджуваної БВМД середньодобові прирости тварин збільшуються на 33-58 г. Відповідно збільшилася і кінцева жива маса тварин на 4,0-7,18 кг проти контрольного рівня. У результаті досліджень, провівши контрольний забій, встановили, шзо згодовування білково-вітамінномінеральної добавки “Ефіпрот” для молодняку свиней на вирощуванні не має вірогідного впливу на масу шлунка, але зумовлює зміни у товщині стінки кардіальної зони на 0,24 мм (2,75\%) та зменшення товщини стінки стосовно контролю на 1,04 мм $(11,91 \%)$. У фундальній зоні шлунка є тенденція до потовщення стінок за рахунок слизової та серезно-м'язової оболонок на 0,36 мм (6,75\%) та 0,35 мм (6,56\%). При дослідженні пілоричної зони спостерігається зменшення товщини стінок порівняно із контрольною групою на 0,46 мм (3,13\%) та 0,73 мм (4,97\%). Реакція кишківника на згодовування “Ефіпрот” молодняку свиней зумовлюється збільшенням маси та довжини на 0,06-0,2 кг та 0,5-0,83 м. Також спостерігається незначне зменшення товщини оболонки порожньої кишки на 0,5 мм (18,3\%), в другій групі тварин на 0,21 мм (7,69 \%). Виявлено суттєву різницю у структурі ободової кишки піддослідних тварин, де мало місие збільшення товщчини стінки у першій групі на 0,13 мм (5,75\%) та зменшення у другій групі на 0,16 мм (7,07\%).

Ключові слова: ефірні олї, молодняк свиней, вирощування, илунок, стінки, кишківник.

\section{Вступ}

У сучасних умовах розвитку тваринництва виробники прагнуть уникати застосування синтетичних компонентів кормосумішей, які трансформуються у тканини живого організму. Тому використання природних екологічно чистих добавках, які одночасно проявляють адаптогенну, корегуючу, імуномоделюючу дію, а при метаболізмі не акумулюються, є актуальним.

Таким вимогам можуть відповідати добавки, які підтримують захисні сили організму, без застосування в годівлі антибіотичних препаратів, що є складовою частиною процесу контролю за здоров'ям молодняку тварин (Stoianovskyi et al., 2014; Pivtorak et al., 2016; Bondarenko, 2016; Martyshuk et al., 2019).

Існує сучасний світовий інтерес щодо використання ароматичних рослин - як нового класу природних добавок у годівлі тварин. Рослинні вторинні метаболіти та рослинні екстракти є цінним резервуаром біоактивних сполук, таких як феноліки, терпеноїди тощо. Відповідно ефірні рослини мають певний вплив на нутригеноміку, впливають на розвиток кишечнику, зміцнюють імунітет (Christaki et al., 2020).

Тваринам 3 високими показниками росту потрібно підтримувати здоров'я, а використання балансуючих добавок є переважаючим аргументом у його підтриманні (Pandey et al., 2019; Khalak et al., 2019; 2020).

Тому для забезпечення повноцінності годівлі тварин вводять до основного раціону кормові та біологічні добавки. Вони застосовуються з метою забезпечення необхідних поживних речовини, підвищення смакової якості корму, покращення показників росту, а також оптимізації використання корму.

Науковцями проведене дослідження із використанням фітобіотиків у харчуванні сільськогосподарської птиці та свиней. Вони здебільшого показали антимікробну, антиоксидантну, протизапальну та стимулюючу дію. Антиоксидативна функція фітобіотиків може позитивно впливати на стабільність кормів для тварин і підвищувати якість продуктів тваринного походження та подовжувати час їхнього зберігання. Зазвичай наукові факти вказують на позитивний вплив фітобіотиків на продуктивність птиці та свиней. Через суперечливість опублікованих результатів необхідні подальші дослідження для з'ясування різних фізіологічних аспектів дії фітобіотиків. (Mohammadigheisar \& Kim, 2017).

Серед них - добавки на основі рослинних ефірних олій. В основу їх входять ароматичні сполуки, одержані дистиляцією з рослинних частин, таких як квіти, бутони, насіння, листя, пагони, кора, деревина, плоди та коріння. Вони характеризуються протизапальною, атрактантною, метаболічною дією, що актуально для годівлі тварин (Giannenas et al., 2013).

3 метою забезпечення безпечності годівлі потрібно з'ясувати, як вплинуть різні кормові добавки на основі ефірних олій на структуру органів травної системи молодняку сільськогосподарських тварин, на процеси живлення. Це $\epsilon$ однією 3 важливих біологогосподарських проблем, пов'язаною 3 формуванням продуктивності сільськогосподарських тварин (Mazurenko et al., 2010).

Тому дослідники звертають увагу на процеси засвоєння компонентів корму організмом. Як відомо, травлення - це складний комплекс фізіологічних i фізико-хімічних процесів, які відбуваються безперервно 3 різною інтенсивністю в різних місцях шлунково-кишкового тракту (Iudina \& Sokolenko, 2015). Тому дослідження дії добавок на основі ефірних олій $\epsilon$ актуальним та потребує подальшого розвитку.

Таким чином, метою роботи було вивчити вплив нової білково-вітамінно-мінеральної добавки на основі ефірних олій на показники продуктивності, реакцію шлунково-кишкового тракту свиней великої білої породи. Ефективність “Ефіпрот” у свинарстві ще не досліджувалась.

\section{Матеріал і методи досліджень}

Дослідження проведені в умовах державного підприємства дослідного господарства "Корделівське" Калинівського району Вінницької області на трьох групах-аналогах молодняку свиней великої білої породи. Відлучення проводилось у 28-добовому віці, групи формувались по 12 голів у кожній. Тваринам дослідних груп в основний період досліду згодовували БВМД “Ефіпрот” з різними концентраціями. 
Таблиця 1

Схема досліду

\begin{tabular}{|c|c|c|c|c|c|}
\hline \multirow{3}{*}{ Групи } & \multirow{3}{*}{$\begin{array}{l}\text { Кількість } \\
\text { тварин в } \\
\text { групі, } \\
\text { гол. } \\
\end{array}$} & \multicolumn{4}{|c|}{ Характеристики годівлі за періодами } \\
\hline & & зрівняльний & & Основний & \\
\hline & & $\begin{array}{c}8-15 \text { кг } \\
(15) \\
\end{array}$ & $\begin{array}{c}15-35 \text { кг } \\
(34)\end{array}$ & $\begin{array}{c}35-65 \text { кг } \\
(38) \\
\end{array}$ & $\begin{array}{c}65-110 \text { кг } \\
(55)\end{array}$ \\
\hline 1 (контрольна) & 12 & $\mathrm{OP}^{\mathrm{x}}$ з БВМД & $\begin{array}{l}\text { ОР з БВМД без ефір- } \\
\text { них олій }\end{array}$ & $\begin{array}{lccc}\text { ОР } & \text { БВВМД } & \text { Без } \\
\text { ефірних олій } & \end{array}$ & $\begin{array}{l}\text { OР } 3 \text { БВМД } \\
\text { ефірних олій }\end{array}$ \\
\hline 2 & 12 & ОР 3 БВМД & $\begin{array}{l}\text { OP } 3 \text { БВМД } \\
\text { "Ефіпрот" - стартер, } \\
400 \text { г/т ефірних олій } \\
\end{array}$ & $\begin{array}{l}\text { ОР } 33 \text { БВМД } \\
\text { "Ефіпрот" - гроуер, } \\
200 \text { г/т ефірних олій }\end{array}$ & $\begin{array}{l}\text { ОР з БВМД “Ефіпрот" } \\
-\quad \text { фінішер, } 150 \text { г/т } \\
\text { ефірних олій }\end{array}$ \\
\hline 3 & 12 & ОР з БВМД & $\begin{array}{l}\text { ОР } 3 \text { БВМД } \\
\text { "Ефіпрот" - стартер, } \\
600 \text { г/т ефірних олій }\end{array}$ & $\begin{array}{l}\text { ОР } 3 \text { БВМД } \\
\text { "Ефіпрот" - гроуер, } \\
400 \text { г/т ефірних олій }\end{array}$ & $\begin{array}{l}\text { ОР з БВМД “Ефіпрот" } \\
-\quad \text { фінішер, } 200 \quad \text { г/ } \\
\text { ефірних олій }\end{array}$ \\
\hline
\end{tabular}

Упродовж дослідження згодовували концентровані корми згідно зі схемою досліду (табл. 1). До складу основного раціону дослідних тварин входили дерть ячменю, пшениці та БВМД “Ефіпрот”. Нестача окремих елементів живлення компенсувалася БВМД “Ефіпрот”, у складі якої налічується тридцять показників, 3 них 10 мінеральної природи, 7 - білкової і 13 - вітамінів. Крім того, добавка містить антиоксиданти, ароматизатор, підкислювач, мультиензим, пробіотик і ефірні олії. А контрольна група споживала стандартну БВМД.

Зважування проводились щомісячно, а облік спожитих кормів проводився щодобово. Структура раціонів змінювались згідно з фазами росту молодняку свиней: маса кожного компоненту раціону, а також відсотковий вміст БВМД. Так, загальна кількість корму збільшувалась від 1 кг/гол. за добу (8-15 кг живої маси), до 1,5 кг/гол. за добу (15-35 кг живої маси), 2,0 кг/гол. за добу (35-65 кг живої маси) і до 2,5 кг/гол. за добу (65-110 кг живої маси).

Після закінчення науково-господарського досліду проводили забій свиней (по 3 голови 3 кожної групи). Шлунок та кишечник зважували, вимірювали довжи- ну та відбирали зразки для морфо-метричних досліджень. Морфологічні дослідження товщини стінок, слизової і серозно-м'язової оболонок проводили після фіксації в 10-процентному нейтральному формаліні за допомогою стереоскопічного мікроскопа МБС-9, користуючись окуляр-лінійкою (Mazurenko et al., 2004)

Біометрична обробка цифрового матеріалу проведена за М. О. Плохінським (Plohynskyj, 1969).

\section{Результати та їх обговорення}

Дослідження показали, що згодовування молодняку свиней БВМД з додаванням ефірних олій не мають негативного впливу на споживання кормів. При цьому виявлено тенденцію до збільшення середньодобових приростів на 33 і 58 г, або на 4,1 і 7,1 \%, при їхньому рівні 791 і 816 г відповідно у другій та третій дослідних групах.

Застосування у раціонах молодняку свиней ефірних олій у складі БВМД в основний період зумовило зменшення маси шлунка у другій, третій групі (табл. 2).

\section{Таблиця 2}

Морфологічні показники шлунка свиней, $\mathrm{M} \pm \mathrm{m}, \mathrm{n}=3$

\begin{tabular}{|c|c|c|c|}
\hline \multirow{2}{*}{ Показник } & \multicolumn{3}{|c|}{ Групи } \\
\hline & 1 (контрольна) & 2 & 3 \\
\hline \multicolumn{4}{|c|}{ Шлунок } \\
\hline Маса шлунка, г & $683 \pm 54,16$ & $633 \pm 40,94$ & $633 \pm 40,94$ \\
\hline \multicolumn{4}{|c|}{ Кардіальна зона } \\
\hline \multicolumn{4}{|l|}{ Товщина стінки, мм } \\
\hline Загальна & $8,73 \pm 0,07$ & $8,49 \pm 0,15$ & $7,69 \pm 0,07$ \\
\hline в т. ч. слизової оболонки & $2,44 \pm 0,14$ & $2,24 \pm 0,19$ & $2,72 \pm 0,22$ \\
\hline серозно-м'язової оболонки & $6,29 \pm 0,10$ & $6,25 \pm 0,05$ & $4,97 \pm 0,12 * * *$ \\
\hline \multicolumn{4}{|c|}{ Фундальна зона } \\
\hline \multicolumn{4}{|l|}{ Товщина стінки, мм } \\
\hline Загальна & $5,33 \pm 0,67$ & $5,69 \pm 0,32$ & $5,68 \pm 0,65$ \\
\hline в т. ч. слизової оболонки & $2,89 \pm 0,19$ & $2,90 \pm 0,12$ & $3,01 \pm 0,11$ \\
\hline серозно-м'язової оболонки & $2,44 \pm 0,47$ & $2,79 \pm 0,22$ & $2,67 \pm 0,56$ \\
\hline \multicolumn{4}{|c|}{ Пілорична зона } \\
\hline \multicolumn{4}{|l|}{ Товщина стінки, мм } \\
\hline Загальна & $14,67 \pm 0,7$ & $14,21 \pm 0,51$ & $13,94 \pm 0,79$ \\
\hline в т. ч. слизової оболонки & $3,14 \pm 0,35$ & $3,20 \pm 0,09$ & $3,23 \pm 0,21$ \\
\hline серозно-м'язової оболонки & $11,73 \pm 0,57$ & $11,01 \pm 0,43$ & $10,71 \pm 0,50$ \\
\hline
\end{tabular}

Примітка: *** - $\mathrm{P} \leq 0,001$ порівняно 3 контрольною групою 
Сам процес всмоктування всіх поживних речовин, які надходять в організм, відбувається виключно в кишечнику. У шлунку деякі речовини підготовлюються до такого стану, в якому вони здатні до подальшого гідролізу і всмоктування (Iudina \& Sokolenko, 2015).

У слизовій оболонці шлунка свиней розрізняють кардіальні залози, фундальні та пілоричні. Вони побудовані з трьох видів секретуючих клітин: головних, обкладових і додаткових (Kostin et al., 1983). Слизова оболонка містить залози та продукує слиз для захисту поверхні від пошкодження грубими кормами і негативної дії шлункового соку. При візуальному спостереженні можна легко виявити ділянки слизової різної структури за кольором. Аналіз морфологічних показників шлунка свиней дослідних групи свідчив про вірогідну різницю змін порівняно з контролем. Так, при згодовуванні нової кормової добавки у кардіальній зоні шлунка свиней дослідних груп зменшилась товщина стінки першої на 0,24 мм $(2,75 \%)$ та другої групи щодо контролю на 1,04 мм (11,91\%).

У фундальній зоні шлунка $є$ тенденція до потовщення стінок за рахунок слизової та серозно-м'язової оболонок на 0,36 мм $(6,75 \%)$ та 0,35 мм (6,56 \%) від- повідно у другій та третій дослідних групах. При дослідженні пілоричної зони спостерігається зменшення товщини стінок шлунка порівняно із контрольною групою на 0,46 мм $(3,13 \%)$ та $0,73(4,97 \%)$.

За використання ефірних олій 150 та 200 г/т комбікорму у годівлі молодняку свиней виявляли збільшення маси та довжини тонкого відділу кишечнику у першої дослідної групи відповідно на 0,06 кг та 0,5 м, а також зменшення товщини стінки за рахунок слизової та серозно-м'язової оболонки на 0,5 мм (18,3\%).

За результатами дослідження показників третьої дослідної групи тварин - маса збільшилась на 0,2 кг, довжина та 0,83 м, при цьому товщина стінки порожньої кишки зменшилась за рахунок слизової та серозно-м'язової оболонки на 0,21 мм (7,69 \%) (табл. 3).

Реакція товстого відділу кишечника на згодовування БВМД “Ефіпрот” проявлялась у змінах його маси та довжини (табл. 4).

Було виявлено суттєву різницю у структурі ободової кишки піддослідних тварин, де мало місце незначне збільшення товщини стінки у другій групі на 0,13 мм $(5,75 \%)$ та зменшення у третій групі на 0,16 мм $(7,07 \%)$.

\section{Таблиця 3}

Морфологічні показники тонкого відділу кишечнику свиней на відгодівлі

\begin{tabular}{lrrr}
\hline \multicolumn{1}{c}{ Показник } & \multicolumn{3}{c}{ Групи } \\
\cline { 2 - 4 } & Тонкий відділ кишечнику & \multicolumn{1}{c}{3} \\
\hline Маса, кг & $1,3 \pm 0,07$ & $1,36 \pm 0,1$ & $1,5 \pm 0,07 * * *$ \\
Довжина, м & $18,83 \pm 2,07$ & $19,33 \pm 2,36$ & $19,66 \pm 3,88$ \\
Товщина стінки дванадцятипалої кишки, мм & $2,73 \pm 0,59$ & $2,23 \pm 0,25$ & $2,52 \pm 0,26$ \\
в т. ч. слизової оболонки, мм & $1,39 \pm 0,29$ & $1,24 \pm 0,01$ & $1,28 \pm 0,19$ \\
серозно-м'язової оболонки, мм & $1,34 \pm 0,22$ & $0,99 \pm 0,12$ & $1,04 \pm 0,05$ \\
\hline
\end{tabular}

Примітка: *** - $\mathrm{P} \leq 0,001$ порівняно $з$ контрольною групою

\section{Таблиця 4}

Морфологічні показники товстого відділу кишечнику

\begin{tabular}{lcc}
\hline \multicolumn{1}{c}{ Показник } & \multicolumn{1}{c}{ Групи } \\
\cline { 2 - 3 } & 1 (контрольна) & 2 \\
\hline Маса, кг & $1,90 \pm 0,18$ & $1,66 \pm 0,16$ \\
Довжина, м & $5,16 \pm 0,54$ & $4,16 \pm 0,21$ \\
Товщина стінки ободової кишки, мм & $2,26 \pm 0,17$ & $2,39 \pm 0,44$ \\
в т. ч. слизової оболонки, мм & $1,27 \pm 0,05$ & $1,33 \pm 0,13$ \\
серозно-м'язової оболонки, мм & $0,99 \pm 0,12$ & $1,06 \pm 0,30$ \\
\hline
\end{tabular}

\section{Висновки}

1. Введення до раціонів молодняку свиней ефірних олій у складі БВМД спричиняє незначне зменшення маси шлунка, проте не викликає змін у товщині стінок окремих його зон. Стінки кардіальної зони зменшились на 2,75-11,91 \%. Однак у фундальній зоні шлунка є тенденція до потовщення стінки за рахунок слизової та серозно-м'язової оболонок на 6,75-6,56 \% В пілоричній зоні спостерігається зменшення товщини стінок порівняно із контрольною групою на 3,13 $4,97 \%$.

2. За використання БВМД “Ефіпрот” у годівлі молодняку свиней відбувається збільшення маси та дов- жини тонкого відділу кишечнику в першої дослідної групи на 0,06-0,2 кг та 0,5-0,83 м.

3. Реакція товстого відділу кишечника на згодовування БВМД “Ефіпрот” проявлялась у змінах його маси та довжини: 5,75-7,07\%.

Подальші дослідження будуть спрямовані на вивчення впливу препарату на біохімічні та морфологічні показники крові свиней.

\section{References}

Bondarenko, V. (2016). Impact of feeding with proteinvitamin mineral supplement "Minaktyvit" on the structure of gastrointestinal tract of young pigs. 
Scientific Messenger of LNU of Veterinary Medicine and Biotechnologies. Series: Agricultural Sciences, 18(2), 29-33. doi: 10.15421/nvlvet6707.

Christaki, E., Giannenas, I., Bonos, E., \& Florou-Paneri, P. (2020). Chapter 2 - Innovative uses of aromatic plants as natural supplements in nutrition, Feed Additives, Academic Press, 2020, 19-34 doi: 10.1016/B978-0-12-814700-9.00002-9.

Giannenas, I., Bonos, E., Christaki, E., \& Florou-Paneri, P. (2013). Essential Oils and their Applications in Animal Nutrition. Medicinal \& aromatic plants, 2(6), 140. doi: 10.4172/2167-0412.1000140.

Iudina, K. Ye., \& Sokolenko, V. M. (2015). Doslidzhennia protiahom $\mathrm{KhKh}$ stolittia protsesiv travlennia $\mathrm{v}$ shlunku svynei Visnyk problem biolohii i medytsyny, 1(117), 50-54 (in Ukrainian).

Khalak, V., Gutyj, B., \& Stadnits'ka, O. (2019). Feeding and meat qualities of young pigs of different origin and intensity of formation in early ontogenesis. Scientific Messenger of LNU of Veterinary Medicine and Biotechnologies. Series: Agricultural Sciences, 21(91), 10-15. doi: 10.32718/nvlvet-a9102.

Khalak, V., Gutyj, B., Bordun, O., Ilchenko, M., \& Horchanok, A. (2020). Effect of blood serum enzymes on meat qualities of piglet productivity. Ukrainian Journal of Ecology, 10(1), 158-161. doi: $10.15421 / 202025$.

Kostin, A. P., Mischerekov, F. A., \& Syisoev A. A. (1983). Fiziologiya selskohozyaystvennyih zhivotnyih. M.: Kolos (in Ukrainian).

Martyshuk, T. V., Gutyj, B. V., \& Vishchur, O. I. (2019). Morphological and biochemical indices of piglets' blood by the action of feed additive "Butaselmevitplus". The Animal biology, 21(4), 65-70. doi: 10.15407/animbiol21.04.065.

Martyshuk, T. V., Gutyj, B. V., Vishchur, O. I., \& Todoriuk, V. B. (2019). Biochemical indices of piglets blood under the action of feed additive "Butaselmevitplus". Ukrainian Journal of Veterinary and Agricultural Sciences, 2(2), 27-30. doi: 10.32718/ujvas2-2.06.

Mazurenko, M. O., Kucheriavyi, V. P., Hutsol, A. V. (2004). Metodychni vkazivky po vyhotovlenniu histolohichnykh preparativ orhaniv i tkanyn tvaryn. Vinnytsia: VDAU (in Ukrainian).

Mazurenko, M. O., Reminnyi, O. I., Hutsol, A. V., Hutsol, N. V., \& Usata, O. I. (2010). Morfolohichni osoblyvosti orhaniv travnoi ta endokrynnoi system svynei pry zghodovuvanni fermentnoho preparatu mek-btu-3. Zbirnyk naukovykh prats VNAU. Hodivlia tvaryn ta tekhnolohiia kormiv, 4(44), 116 (in Ukrainian).

Mohammadigheisar, M., \& Kim, I. H. (2017). Phytobiotics in poultry and swine nutrition - a review. Italian Journal of Animal Science, 17(1), 1-8. doi: 10.1080/1828051X.2017.1350120.

Pandey, A. K., Kumar, P., \& Saxena, M. J. (2019). Feed Additives in Animal Health. In: Gupta R., Srivastava A., Lall R. (eds) Nutraceuticals in Veterinary Medicine. Springer, Cham. doi: 10.1007/978-3030-04624-8 23.

Pivtorak, J., Bogdan, I., \& Vinnichenko, G. (2016). Fatlening and meat qualities of swine during feding up with probiotic additives "PROPYGplv" as a part of the ration. Scientific Messenger of LNU of Veterinary Medicine and Biotechnologies. Series: Agricultural Sciences, 18(2), 13-17. doi: 10.15421/nvlvet6703.

Plokhynskyi, N. A. (1969). Rukovodstvo po byometryy dlia zootekhnykov [Guide forbiometrics for livestock]. Moskow: Kolos (in Ukrainian).

Stoianovskyi, V. H, Kamratska, O. I, Kolomiiets, I. A., \& Matsiuk, O. I. (2014). Synbiotyky dlia porosiat mekhanizm dii. perevahy zastosuvannia. NV LNU veterynarnoi medytsyny ta biotekhnolohii. Seriia: Veterynarni nauky, 16(60), 314-320 (in Ukrainian). 